
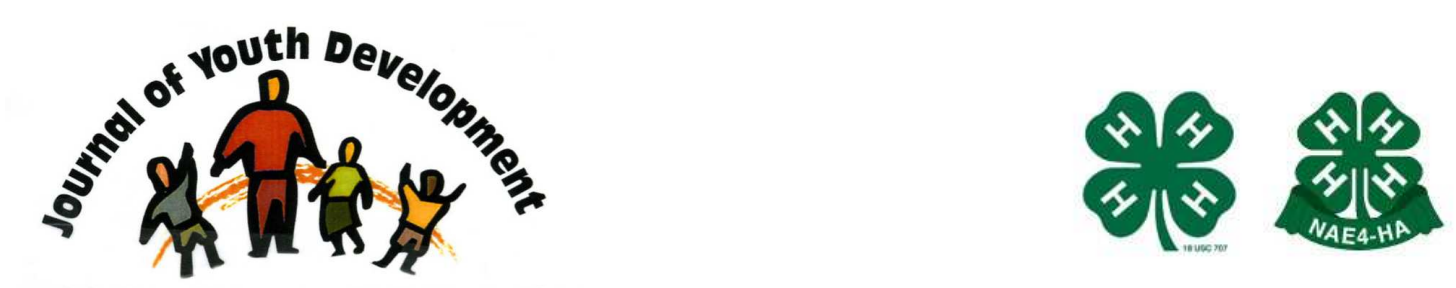

Bridging Research \& Practice

\title{
Extension Staffing Models to Serve 4-H Clientele in Changing Times
}

\author{
Donna R. Gillespie \\ University of Idaho Extension \\ Rupert, ID \\ donna@uidaho.edu \\ Cindy A. Kinder \\ University of Idaho Extension \\ Gooding, ID \\ ckinder@uidaho.edu
}




\title{
JOURNAL OF YOUTH DEVELOPMENT \\ bridging research and practice

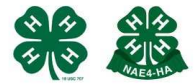

Volume 5, Number 1, Spring 2010

Article 100501PA004

\section{Extension Staffing Models to Serve 4-H Clientele in Changing Times}

\author{
Donna R. Gillespie and Cindy A. Kinder \\ University of Idaho Extension
}

\begin{abstract}
In response to budget cuts in 2002, 4-H staffing models were restructured. The response by University of Idaho Extension was intended to continue meeting the needs of Idaho's citizens with fewer UI Extension faculty. This staffing reorganization led to the formation of the District III 4-H Team who united to bring stronger 4-H programs to south central Idaho and expand programs to underserved audiences.

Information from surveys and interviews over the past seven years reflects the effectiveness, challenges and successes of the District III 4-H Team. In Making the Best Better: 4-H Staffing Patterns and Trends in the Largest Professional Network in the Nation (2007), author Kirk A. Astroth notes a nationwide change in 4-H leadership at the county level from 4-H faculty to program assistants or coordinators. The information gathered in our research may help other states determine staffing models to meet the needs of clientele in these changing times.
\end{abstract}

\section{Introduction}

In response to budget cuts in 2002, University of Idaho (UI) Extension 4-H programming in District III was restructured. The restructuring reflected recommendations made by UI Extension Advisory Board members from around the state as well as other 4-H Youth Development stakeholders, including volunteer leaders, Extension Educators and key community leaders. This proactive response by UI Extension was designed to find new ways to continue serving the public as effectively as possible with fewer UI faculty and lead to the formation of the District III 4-H Team. The Team is comprised of eight County 4-H Program Coordinators and two Area 4-H/Youth Extension Educators who united in an effort to bring stronger 4-H programs to south central Idaho (District III) and expand programs to underserved audiences. 
How was this model different than before? How could less staff have greater impact and expand audiences? Do statistical results show increased numbers?

Staffing models such as the District III 4-H Team are not new to Extension, although the names and terminology are changed to reflect the region or program being defined. There has been a nationwide change in 4- $\mathrm{H}$ leadership from 4- $\mathrm{H}$ faculty to program assistants or coordinators at the county level (Astroth, 2007). Clustering has been in existence in Minnesota since 1987 (Hutchins, 1992). Minnesota Extension adopted a regional and county delivery model in 2004 because of the fiscal crisis which affected all state agencies, educational institutions and local governments (Morse, 2006). In Indiana paid paraprofessionals were incorporated into the county 4-H staffing model as an alternative to the reduction in the number of professional youth agent positions (Ritchie \& Stitsworth, 1987). As with all youth development programs, challenges and opportunities continue. Extension has continued to evolve, adapt and meet these challenges.

\section{Methodology}

The District III 4-H Team is made up of eight neighboring County 4-H Program Coordinators who are responsible for the daily operation and support of local programming, including working with County 4-H councils, livestock committees, data collection and entry, county youth camps, county fairs and other organizational duties. Two Area 4-H Extension Educators serve the Team by providing programming, professional development, and guidance for policy implementation to the County 4-H Program Coordinators/Assistants.

Team meetings are held monthly, from September through April, to address the District's needs for program support and provide training to reach the goals outlined in the University of Idaho 4-H Youth Development Statewide Strategic Plan. In addition, Team members are encouraged to attend other professional development opportunities such as statewide $4-\mathrm{H}$ trainings and the Idaho 4-H Leaders Forum. Team meeting topics have included team building, understanding and using the logic model, animal quality assurance, personal productivity, diversity training, teen activities, effective meetings, judge exchanges, skill-a-thons, and many more. The Team also addresses questions and concerns about county leader associations, livestock sale committees and advisory councils.

In 2003, after one year of operation, a survey was conducted with Team members to evaluate the effectiveness of the new staffing model. A survey of District III 4-H volunteers, members and families was conducted in 2005 to determine if after three years a strong Team effort had actually improved district-wide programming for area clientele. In addition, interviews were conducted in 2007 with all county Extension faculty and staff to evaluate the changes in county operations and the level of support from non-4-H faculty, including budget and time concerns of county chairs or county Extension Directors.

\section{Findings}

\section{Team Member Responses:}

Results from the 2003 survey with Team members indicated that they rank monthly staff meetings as a positive change and extremely valuable. They also felt their county 4-H programs were improving because of the Team effort. Respective staff members are more knowledgeable about 4- $\mathrm{H}$ issues, and consequently better able to handle them. Team members 
also appreciate the support for district-wide activities and the consistency of information provided by the Area 4-H Extension Educators.

Team members were asked several questions that compared their work before and after the formation of the Team. The coordinators showed an increase in partnerships with other coordinators on district activities and the majority felt more confident in the activities they conducted after the Team effort began.

All Team members attended $100 \%$ of the monthly meetings held the first year; which is an indication that they are educational and a worthwhile use of their time. In addition, all Team members also shared information gained with other faculty and staff at their respective county meetings, and all reported that their office perceived the monthly meetings as worthwhile.

Other comments from the 2003 survey:

- The District Team keeps us up-to-date with changes in the state and how they affect the programs in our counties.

- I have more freedom in making decisions concerning our county 4-H program.

- When I have a question I feel I can throw it out to the Team and get feedback. Then I can proceed without so much trial and error. My program is more consistent with other counties.

- I feel the volunteers can ask me questions and I will find the answer. Confidence in me as a resource has improved.

- I am able to get other ideas, forms or information quickly and it saves time in having to develop something that has already been done.

- No one has ever asked me in my 15 years what I need to know or learn to do a better job. The Area 4-H Extension Educators are providing what we want and need. Thanks!

\section{Clientele Responses:}

The 2005 survey asked District III 4-H volunteers, members, and families to designate which county and district councils and boards they were active in and to evaluate their leadership. A list of 22 District III activities was also provided and participants were asked to indicate if they attended the activity, if they did not attend but received the information and from what source they received it. Information about how district-wide activities encourage families to stay involved and how these activities benefited youth in the community was also collected. Participants were encouraged to rate the response they received when asking questions about 4-H.

The surveys returned were $60 \%$ from volunteer leaders, $30 \%$ parents and $10 \%$ youth. Respondents stated they were active in District III 4-H Leaders Council, Horse and Pony Council, Central Idaho 4-H Camp Board, county leader councils, county 4-H advisory boards, teen councils and/or market animal sale committees. Seventy seven percent indicated they had seen a positive change in leadership of these councils and boards due to the programming efforts of the Team.

The 2005 surveys also showed that 4-H families were receiving information from several sources including County 4-H Program Coordinators, Area 4-H Extension Educators, other UI Extension Educators and county office secretaries. When asked how they would rate the responses they received to their questions, $85 \%$ said they received a clear answer, and $15 \%$ indicated the answer they received may have been unclear but the source knew where to go to 
find the answer. Eventually, $100 \%$ of the participants received clear, accurate information in response to their $4-\mathrm{H}$ questions. No one indicated that they were unable to find help or that their questions went unanswered.

Other comments from the 2005 survey:

- District-wide activities have made me a better leader and have helped spur interest in members.

- The positive change in leadership has made me more involved, the county more diverse and all more active and involved.

- The district effort involves more kids in great activities.

- There are more opportunities through strong communication.

- I have little experience in 4-H but with the great organization - and I do mean "organized" I am able to make a quick call and make sure I am on the proper track and aligned with 4-H guidelines.

- $\quad$ The leadership effort keeps me encouraged to stick with the 4-H program as a volunteer and parent of $4-\mathrm{H}$.

- Our county is kept informed on what is going on with other counties in District III.

- With more communication there are more programs and better run programs.

- I have seen positive reinforcement, leadership and knowledge and more scholarship opportunities.

\section{County Extension Office Responses:}

In 2007, the two Area 4-H Extension Educators visited each of the eight county Extension offices included in the Team and met with county chairs, other Educators with 4-H responsibilities and the 4-H County Coordinators/Assistants. They felt this was the next step for the Team and wanted to make sure the needs of the county and constituents were being met. The meeting format included asking participants to:

- Provide a brief update of what the Team has accomplished in the past four years

- Assess your county needs and how the Team fits into them

- Discuss the goals set by the Team and how we are addressing them

- Review Team expectations. What does the Team do for your county? Are we meeting your needs?

Results of the interviews proved to be as varied as the counties in which they were conducted. County chairs expressed both support of the program and caution about time spent out of the county, compensatory time and travel budget issues. Team members' comments seemed to vary based on the support they were receiving from their county and their length of service.

\section{Other comments from the 2007 survey:}

- A Team member expressed concerns over "pressure" to participate in district activities and their county chair asked about professional development offered at the Team meetings.

- A county chair indicated that he was "protective" of the hours the Team member worked out of the county since the county supported part of her salary. The Team member hadn't done a good job explaining the Team concept to the rest of the faculty and staff and didn't appear comfortable asking for help from the Area 4-H Extension Educators. 
- The county chair said she is a "total advocate" of the Team approach but felt the "professionalism" of the Team members is not as well supported from other faculty as it should be. The Team member said the district activities planned by the Team are "the greatest" and saved her time and effort while providing more opportunities for her 4-H families.

- The county chair (oversees two counties) was a member of the Team and both her county Team members felt the professional development opportunities were very helpful. They have both been on staff several years and commented that they remember how little communication there was before the Team was formed.

- A Team member indicated that when she was first employed the Team played an important part and she learned a lot, but not as much now. She did also indicate that the professional development offered at the meetings was always helpful. The county chair expressed concern about compensatory time issues and too much involvement in district activities. He also felt the Area 4-H Extension Educators, who are tenure-track faculty, were taking too much credit for the work the county staff did.

- A county chair reported he was very satisfied with the Team because of the reports he got back from his Team member. The Team member said that the district activities supported by the Team added value to her county program.

- The Team member felt the Team was more of a time saver than extra work and wasn't comfortable asking for help from other counties before the Team was formed, but shares information all the time now. The county chair was also a member of the Team, she supports the concept and pointed out that other Extension faculty were now working in district teams

\section{Conclusion}

A perceived but undocumented shift in 4-H staffing has been present since 1990 (Astroth, 2007). Concerns of the complicated relationships between traditional 4-H Extension Educators and County 4-H Program Coordinators and the programs they can maintain are ongoing. One thing for certain is that 4-H staffing models are adapting to meet budget restrictions, personnel availability, and the continuing changes in stakeholder demands. With restructuring, Minnesota Extension was able to make shifts that lead to greater program impacts and greater access to specialized field staff (Morse, 2006). Astroth also noted that turnover is high in youth work so organizations struggle to retain workers, increase satisfaction, and reduce burnout (Astroth, 2007).

The District III 4-H Team is a unique group of Extension Educators, County 4-H Program Coordinators and County 4-H Program Assistants who have met these challenges head on to deliver quality youth development programs to area families. Although the group is not without challenges, including out of county travel, varying professional development needs, differences in personalities, learning styles and most importantly county support, it has continued to function since 2002. The most important lessons learned by the Area 4-H Extension Educators who guide this group are to maintain communication at all levels, including non-4-H faculty and county chairs and to continue to encourage active participation by all Team members to insure adequate professional development opportunities and job satisfaction.

\section{References}


Astroth, K.A. (2007). Making the Best Better: 4-H Staffing Patterns and Trends in the Largest Professional Network in the Nation. Journal of Youth Development (2:2). On-line at: http://www.nae4ha.org/directory/jyd/jyd article.aspx?id=fbd6a179-96a4-4ca6-bc98$\underline{2429 b c a d 1740}$

Gillespie, D.R., \& Kinder C.A. (2003). District III 4-H Team - Making the Best Better. University of Idaho Extension Impact Statements.

Gillespie, D.R., \& Kinder C.A. (2006). District III 4-H Team - Programs Reaching Families. University of Idaho Extension Impact Statements. On-line at:

http://www.extension.uidaho.edu/impacts/Pdf 06/18-06dgillespie-families.pdf

Hutchins, G.K. (1992). Evaluating County Clustering. Journal of Extension (30:1). On-line at: http://www.joe.org/joe/1992spring/a5.html

Morse, G.W. (2006). Minnesota Extension's Regional and County Delivery System: Myths and Reality, Journal of Extension (44:4). On-line at:

http://www.joe.org/joe/2006august/comm1p.shtml

Ritchie, R.M., \& Stitsworth, M.H. (1987). Carving a Niche, Journal of Extension (25:3). On-line at: http://www.joe.org/joe/1987fall/a3.html.

(C) Copyright of Journal of Youth Development Bridging Research and Practice. Content may not be copied or emailed to multiple sites or posted to a listserv without copyright holder's express written permission. However, users may print, download or email articles for individual use. 